\title{
ECHDC3 Gene
}

National Cancer Institute

\section{Source}

National Cancer Institute. ECHDC3 Gene. NCI Thesaurus. Code C162359.

This gene may play a role in fatty acid metabolism. 